\title{
Prevalence of Gastroesophageal Reflux of Wheezers in Infancy and Early Childhood
}

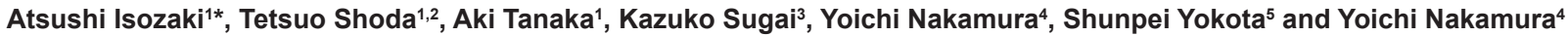 \\ ${ }^{1}$ Divison of Pediatrics, Medical Center for Allergy and Immune Diseases, Yokohama City Minato Red Cross Hospital, Japan \\ ${ }^{2}$ Division of Allergy, Department of Medical Specialties, National Center for Child Health and Development, Japan \\ ${ }^{3}$ Department of Pediatrics, National Hospital Organization Yokohama Medical Center, Japan \\ ${ }^{4}$ Department of Allergology, Medical Center for Allergy and Immune Diseases, Yokohama City Minato Red Cross Hospital, Japan \\ ${ }^{5}$ Department of Pediatrics, Yokohama City University, Japan
}

\begin{abstract}
Background: Gastroesophageal reflux (GER) has largely been recognized as a physiological phenomenon in infancy and early childhood and the relationship of severe, recurrent wheezing to gastroesophageal reflux disease (GERD) has been well described. However it has remained unclear how many mildly wheezy infants are complicated by GER.
\end{abstract}

Objective: This study investigated the prevalence of GERD among wheezers in infancy and early childhood in Japan. Subjects and Method: We evaluated esophageal pH monitoring in wheezy children under 2 years old.

Results: A positive $\mathrm{pH}$ index was found in $9.4 \%$ of all subjects.

Conclusion: Although the prevalence of GERD among severe wheezers was higher in previous reports, our study concluded that the prevalence of GERD among wheezers was lower in younger children.

Keywords: Gastroesophageal reflux; Infant; pH index; Wheezer

\section{Introduction}

In some severe recurrent wheezers who do not respond to asthma medication including inhaled corticosteroids, wheezing is caused by gastroesophageal reflux (GER) [1-2]. However, physiological GER is largely recognized in younger children [3] and gastroesophageal reflux disease (GERD) manifests various symptoms other than wheezing [4]. It remains unclear how GER is associated with wheezing. Additionally, it has not yet been determined whether recurrent wheezers in infancy later develop asthma. Therefore, we evaluated the prevalence of GER among infantile wheezers by 24 -hour esophageal $\mathrm{pH}$ monitoring (EpHM)

\section{Object}

This study investigated the prevalence of GERD among general wheezers in infancy and early childhood in Japan.

\section{Subjects and Methods}

The subjects were included in this study prospectively. 32 patients were admitted to Yokohama City Minato Red Cross Hospital because of wheezy exacerbation. The mean months of age in this patient group was $12.7 \pm 5.2$ (range: 3 to 24 ). Past patient and family medical histories, laboratory data including serum IgE, peripheral eosinophils counts, specific-IgE (ImmunoCAP, Phadia AB, Sweden) including air-borne antigens: mites, house dust and Japanese cedar, and food-antigens: egg-white, cow's milk and wheat, and rapid Respiratory Syncytial virus antigen test of nasal swab were analyzed (Check RSV, SA Scientific Inc., USA). 11 of 32 patients (34.4\%) were positive sensitization to aeroantigens and 17 patients (53.1\%) ware positive sensitization to food antigens. 8 patients $(25.0 \%)$ had treated as diagnosed asthma taking controller medication at admission, all had taken leukotriene receptor antagonist (4mg/day) and 3 patients had budesonide inhalation suspension $(0.5 \mathrm{mg} /$ day $)$ together.

All patients were treated with systemic administration of corticosteroids (soluble prednisolone $0.5 \mathrm{mg} / \mathrm{kg} \times 4 /$ day) and inhaled beta stimulant (salbutamol $0.1 \mathrm{ml} \mathrm{q} 4-8 \mathrm{hrs}$ ) for 4 or 5 days after admission. Twenty-four-hour esophageal $\mathrm{pH}$ monitoring (EpHM) was performed on the 6th or 7th hospitalized day after completion of acute treatment when the respiratory state had stabilized and wheeze, tachypnea and desaturation had disappeared (PH 101 ZS, Chemical Instruments CO., LTD., Japan). The ratio of the duration of $\mathrm{pH}$ less than 4.0 within the 24 -hour monitoring period was expressed as the $\mathrm{pH}$ index. A positive $\mathrm{pH}$ index was defined as a ratio of $4 \%$ or higher [6]. In addition to $\mathrm{pH}$ index, we also calculated the numbers of reflux episodes while awake as defined by a number of episodes showing $\mathrm{pH}<$ 4.0, based on the previous report by Yoshida et al. [7].

\section{Results}

Among these 32 patients, 3 patients (9.4\%) were found to have GER based on EpHM. The mean $\mathrm{pH}$ index based on the ratio of time under pH 4.0 was 1.36 (SD; 1.82) \%. The mean numbers of reflux episodes while awake was $2.9(\mathrm{SD} ; 3.4) / \mathrm{hr}$.

\section{Discussion}

Although it has been demonstrated that GER causes severe recurrent wheeze in infancy and early childhood, there are limited data on the prevalence of GER among wheezers in younger children,

*Corresponding author: Atsushi Isozaki, Department of Pediatrics, Medical Center for Allergy and Immune Diseases, Yokohama City Minato Red Cross Hospital, 3-12-1 Shin-yamashita, naka-ku, Yokohama City, Japan, Tel. +81-456100; Fax.+81-45-6101; E-mail: isozaki.ped@yokohama.jrc.or.jp

Received October 07, 2011; Accepted November 20, 2011; Published November 25, 2011

Citation: Isozaki A, Shoda T, Tanaka A, Sugai K, Nakamura Y, et al. (2011) Prevalence of Gastroesophageal Reflux of Wheezers in Infancy and Early Childhood. J Aller Ther S4:002. doi:10.4172/2155-6121.S4-002

Copyright: @ 2011 Isozaki A, et al. This is an open-access article distributed unde the terms of the Creative Commons Attribution License, which permits unrestricted use, distribution, and reproduction in any medium, provided the original author and source are credited. 


\begin{tabular}{|l|l|}
\hline $\mathrm{N}$ & 32 \\
\hline age (m/o) & $12.7(5.2)$ \\
\hline sex, male & $23(71.9 \%)$ \\
\hline birth at gestational age (week) & $37.0(3.04)$ \\
\hline weight of birth $(\mathrm{g})$ & $2781.5(589.9)$ \\
\hline first episode of wheeze (m/o) & $6.5(3.8)$ \\
\hline serum IgE (IU/ml) & $192.0(515.9)$ \\
\hline peripheral eosinophils count $(\mu \mathrm{L})$ & $500.2(440.9)$ \\
\hline positive sensitization to aeroantigens & $11(34.4 \%)$ \\
\hline positive sensitization to food antigens & $17(53.1 \%)$ \\
\hline complete breast-fed & $13(40.6 \%)$ \\
\hline daycare attendance & $18(56.3 \%)$ \\
\hline having siblings & $16(50.0 \%)$ \\
\hline having pets & $8(25.0 \%)$ \\
\hline exposure of smoker & $15(46.9 \%)$ \\
\hline atopic dermatitis & $6(18.8 \%)$ \\
\hline food allergy & $8(25.0 \%)$ \\
\hline parental bronchial asthma & $9(28.1 \%)$ \\
\hline febrile state of admission & $20(62.5 \%)$ \\
\hline RSV infection at admission & $6(18.8 \%)$ \\
\hline previous asthma controller medication & $8(25.0 \%)$ \\
\hline leukotriene receptor antagonist (4mg/day) & $8(25.0 \%)$ \\
\hline budesonide inhalation suspension (0.5mg/day) & $3(9.4 \%)$ \\
\hline
\end{tabular}

Data are expressed as number (ratio) or mean (SD).

Table 1: Clinical characteristics of subjects.

\begin{tabular}{|l|l|}
\hline $\mathrm{pH}$ index $>=4 \%$ & $3 / 32(9.4 \%)$ \\
\hline $\mathrm{pH}$ index (\%) & $1.36(1.82)$ \\
\hline numbers of reflux episodes at awake (/hr) & $2.9(3.4)$ \\
\hline
\end{tabular}

† EpHM; esophageal pH monitoring

Data are expressed as number (ratio) or mean (SD).

Table 2: Results of EpHM †

\begin{tabular}{|l|l|l|l|l|}
\hline $\begin{array}{l}\text { Author (year), } \\
\text { location }\end{array}$ & Age, y & Study design & $\begin{array}{l}\text { Sample } \\
\text { size N }\end{array}$ & $\begin{array}{l}\text { Prevalence of } \\
\text { Reflux n/N (\%) }\end{array}$ \\
\hline $\begin{array}{l}\text { Gorenstein et al } \\
\text { (2003), Israel [8] }\end{array}$ & $\begin{array}{l}\text { Mean (SD): } 1.4 \\
(2.8)\end{array}$ & Retrospective & 153 & $64 / 153(41.8)$ \\
$\begin{array}{l}\text { Teixeira et al } \\
\text { (2007), Brazil [9] }\end{array}$ & Mean: 2.6 & Prospective & 69 & $47 / 69(68.1)$ \\
$\begin{array}{l}\text { Present study } \\
\text { Japan }\end{array}$ & $\begin{array}{l}\text { Mean (SD): } 1.1 \\
(0.4)\end{array}$ & Prospective & 32 & $3 / 32(9.4)$ \\
\hline
\end{tabular}

Table 3: Pediatric studies that examined GERD in indivisuals with asthma in early childhood.

especially infants. Our data demonstrated that the prevalence of GER among wheezers in younger children was only 3 of 32 patients $(9.4 \%)$.

In a study of 47 severe, recurrent wheezers ranging from 5 to 58 months old, Saglani and colleagues reported that GER was the predominant cause [2]. In that study, the frequency of GER was $23 \%$ among their subjects, that of asthma was $41 \%$ and 11 of 19 patients with definite asthma also had GER, as defined by abnormal $\mathrm{pH}$. In a study limited to younger children, Gorenstein and colleagues reported that the prevalence of GERD was $41.8 \%$ among 153 asthmatic children aged $1.4(\mathrm{SD} ; 2.8)$ years old [8]. Teixeira and colleagues indicated that the prevalence of GERD was $68.1 \%$ in 69 patients with a mean age of 2.6 years old [9].

There is a difference in the prevalence of GERD among asthmatic children between the present study and previous reports. Demographic differences may be reflected in the results of our study. Brand and colleagues proposed phenotypes of wheezing disorders in pre-school children as episodic wheeze and multiple-triggered wheeze based on temporal pattern [10]. Although the previous study included more severe multiple-triggered wheezers, our study included not only multiple-triggered wheezers but also episodic wheezers.

Although the prevalence of GERD among severe wheezers was higher in previous reports, our study concluded that the prevalence of GERD among general wheezers is lower in younger children.

\section{References}

1. Khoshoo V, Le T, Haydel RM Jr, Landry L, Nelson C (2003) Role of gastroesophageal reflux in older children with persistent asthma. Chest 123 1008-1013.

2. Saglani S, Nicholson AG, Scallan M, Balfour-Lynn I, Rosenthal M, et al. (2006) Investigation of young children with severe recurrent wheeze: any clinical benefit? Eur Respir J 27: 29-35

3. Colletti RB, Di Lorenzo C (2003) Overview of pediatric gastroesophageal reflux disease and proton pump inhibitor therapy. J Pediatr Gastroenterol Nutr 37 S7-S11.

4. Vandenplas Y, Ashkenazi A, Belli D, Boige N, Bouquet J, et al. (1993) A proposition for the diagnosis and treatment of gastro-oesophageal reflux disease in children: a report from a working group on gastro-oesophagea reflux disease. Working Group of the European Society of Paediatric Gastroenterology and Nutrition (ESPGAN). Eur J Pediatr 152: 704-711.

5. Castro-Rodríguez JA, Holberg CJ, Wright AL, Martinez FD (2000) A clinical index to define risk of asthma in young children with recurrent wheezing $\mathrm{Am} \mathrm{J}$ Respir Crit Care Med :162: 1403-1406.

6. Rudolph CD, Mazur LJ, Liptak GS, Baker RD, Boyle JT, et al. (2001) North American Society for Pediatric Gastroenterology and Nutrition. Guidelines for evaluation and treatment of gastroesophageal reflux in infants and children: recommendations of the North American Society for Pediatric Gastroenterology and Nutrition. J Pediatr Gastroenterol Nutr 32: S1-31.

7. Yoshida Y, Kameda M, Nishikido T, Takamatu I, Doi S (2008) Gastroreflux diseases in preschool children with asthma. Arerugi 57: 529-535.

8. Gorenstein A, Levine A, Boaz M, Mandelberg A, Serour F (2003) Severity of acid gastroesophageal reflux assessed by $\mathrm{pH}$ metry: is it associated with respiratory disease? Pediatr Pulmonol 36: 330-334.

9. Teixeira BC, Norton RC, Penna FJ, Camargos PA, Lasmar LM, et al. (2007) Gastroesophageal reflux and asthma in childhood: a study on their relationship using esophageal PH monitoring. J Pediatr (Rio J) 83: 535-540.

10. Brand PL, Baraldi E, Bisgaard H, Boner AL, Castro-Rodriguez JA, et al. (2008) Definition, assessment and treatment of wheezing disorders in preschool children: an evidence-based approach. Eur Respir J 32: 1096-1110. 